\title{
DFT study of triplet and singlet elementary acts of acyclic and cyclic alkanes oxidation initiated by primary interaction with ${ }^{3} \mathrm{O}_{2}$
}

\author{
(C) Alexandre I. Kourdioukov, ${ }^{1,3} *^{+}$Vener F. Khayrutdinov, ${ }^{2}{ }^{+}$Farid M. Gumerov, ${ }^{2 *}$ \\ Asia R. Gabitova, ${ }^{2}$ Ilfat Z. Salikhov, ${ }^{2}$ Vladimir G. Uryadov, ${ }^{3}$ Evgeny N. Ofitserov, ${ }^{3,4}$ \\ Aynur F. Mingaliev, ${ }^{1,3}$ and Alexey V. Trofimov ${ }^{5}$ \\ ${ }^{1}$ Center for New Information Technologies; ${ }^{2}$ Department of Theoretical Foundations of Heat Engineering; \\ Kazan National Research Technological University. K. Marx St., 68. Kazan, 420015. Republic of Tatarstan. \\ Russia. Phone: ${ }^{1)}+7$ (843) 231-42-30; ${ }^{2)}+7$ (843) 231-42-11. \\ ${ }^{3}$ Butlerov Scientific Foundation. Bondarenko St., 33-44. Kazan, 420066. Republic of Tatarstan. Russia. \\ E-mail: butlerov@mail.ru; vguryadov@mail.ru \\ ${ }^{4}$ Department of Chemistry and Technology of Biomedical Preparations. Faculty of Chemical Pharmaceutical \\ Technologies and Biomedical Preparations. D.I. Mendeleev Russian University of Chemical Technology. \\ Miusskaya Sq., 9. Moscow, 125047.Russia.Phone: +7 (495)978-32-61.E-mail: ofitser@mail.ru \\ ${ }^{5}$ N.M. Emanuel Institute of Biochemical Physics. RAS. Kosygina St., 4. Moscow, 119334. Russia.
}

*Supervising author; ${ }^{+}$Corresponding author

Keywords: alkanes, cycloalkanes, molecular oxygen, oxygen-induced C-H bond cleavage, triplet hydrogen complexes, triplet recombinations, triplet transformations, alkyl radicals, hydroperoxyl radical, organic hydroperoxides, reaction mechanisms, elementary events, DFT method.

Abstract
The primary oxidation stages of ${ }^{3} \mathrm{O}_{2}$ model acyclic and cyclic alkanes and their subsequent triplet and
et elementary events were studied for the first time by the DFT method with the density functional B3LYP and basis set $6-311++\mathrm{g}(\mathrm{df}, \mathrm{p})$.

According to quantum chemical DFT calculations the $\mathrm{C}-\mathrm{H}$ radical cleavage of the bonds of acyclic and cyclic alkanes upon interaction with ${ }^{3} \mathrm{O}_{2}$ is almost completely thermodynamically shifted toward the initial state of the reaction system. This energy of primary oxidizing events explains the extremely low reactivity of saturated alkanes in comparison with asphaltene structural fragments under the conditions of SCF technology for the extraction of heavy oils and asphaltenes by a propane-butane mixture.

It has been demonstrated that for all elementary acts of primary alkane oxidation the product of the direct reaction direction is not a free pair of radicals but a triplet hydrogen complex with a pronounced hydrogen bond between the hydroperoxyl radical and the radical form of the corresponding hydrocarbon.

A new, previously not taken into account very exothermic $(\Delta \Delta \mathrm{H}=-29.25--30.77 \mathrm{kcal} / \mathrm{mol})$ reaction direction is described which corresponds to triplet recombination of alkyl radicals and a hydroperoxyl radical in its oxygen-concentrated part. The products of this recombination are triplet forms of alkane hydroperoxides in which there is a fairly loosened triplet O---O bond with a length of 2.20-2.23 $\AA$, which is $\sim 0.72-0.77 \AA$ more than bond length in the singlet state.

\section{References}

[1] Ya.B. Zeldovich, A.L. Buchachenko, E.L. Frankevich. Magnetic spin effects in chemistry and molecular physics. Advances in Physical Sciences. 1988. Vol.155. No.1. P.3-45. (Russian); K.M. Salikhov. 10 Lectures on spin chemistry. Kazan: UNIPRESS Publishing House. 2000.152p. (Russian)

[2] N.S. Akhmetov. General and inorganic chemistry. Textbook for universities. 4th ed., Rev. Moscow: Higher School Ed. Center "Academy". 2001.743p. (Russian); V.V. Teplov and S. Ovcharenko. The Editor Professor V.V. Negrebetsky. Teaching aid "Inorganic chemistry" for students of biomedical science. Part 1. General chemistry ". RNIMU. 2014. 115p. (Russian)

[3] A.L. Buchachenko. Chemical polarization of electrons and nuclei. Moscow: Science. 1974. 246p. (Russian)

[4] G. Closs, A. Trifunac. J. Am. Chem. Soc. 1970. 92. C.2186.

[5] N. Turro. Molecular photochemistry. Editor R.F. Vasilyeva. Moscow: Publishing House "Mir". 1967. 328p. (Russian) 
[6] A.I. Kourdioukov, A.R. Gabitova, F.M. Gumerov, E.N. Ofitserov, and D.L. Egorov. Quantum-chemical study of the transformation of triglycerides. Part 4. Elementary acts of supercritical water oxidation (SCWO) model analogs fatty acid triglycerides in supercritical fluid media. Butlerov Communications. 2015. Vol.44. No.10. P.153-197. DOI: 10.37952/ROI-jbc-01/15-44-10-153

[7] A.I. Kourdioukov, V.F. Khayrutdinov, F.M. Gumerov, A.R. Gabitova, V.G. Uryadov, A.F. Mingaliev, and E.N. Ofitserov. The triplet biradical states of the arenes, as a basis for paramagnetic centers of asphaltenes and a source of soft radical thermolysis in SCF-extraction processes for processing super viscous oil and resin-asphaltene mixtures. Butlerov Communications. 2017. Vol.52. No.10. P.1-16. DOI: 10.37952/ROI-jbc-01/17-52-10-1

[8] A.I. Kourdioukov, Vener F. Khayrutdinov, F.M. Gumerov, A.R. Gabitova, V.G. Uryadov, A.F. Mingaliev, and E.N. Ofitserov. Triplet oxygen-water associates as the main agents of acidifying autocatalytic redoxprocesses. Quantum-chemical description of primary elementary acts of combustion. Butlerov Communications. 2017. Vol.52. No.10. P.17-27. DOI: 10.37952/ROI-jbc-01/17-52-10-17

[9] N.M. Emanuel, E.T. Denisov, Z.K. Maizus. Chain reactions of oxidation of hydrocarbons in the liquid phase. Moscow: Science. 1965. 375p. (Russian); W. Waters. Mechanism of Oxidation of Organic Compounds. Moscow: Mir. 1966. 258p. (Russian)

[10] I.P. Skibida Molecular oxygen activation by metal complexes and its role in the mechanism of liquidphase oxidation. Advances in Chemistry. 1985. Vol.LIV. No.9. P.1487-1504. (Russian)

[11] N.E. Damoyi, H.B. Friedrich, H.G. Kruger, D. Willock. Density Functional Theory Studies of the Uncatalysed Gas-Phase Oxidative Dehydrogenation Conversion of n-Hexane to Hexenes. Computational and Theoretical Chemistry. 2017. Vol.1114. P.153-164.

[12] V.F. Khairutdinov, A.R. Gabitova, F.M. Gumerov, R.F. Gabitov, A.I. Kourdioukov. Extraction of oil products and resin-asphaltene mixtures from highly watered oil sludge by supercritical fluid extraction. Supercritical Fluids: Theory and Practice. 2018. Vol.13. No.3. P.97-102. (Russian); F.M. Gumerov, V.F. Khairutdinov, T.R. Akhmetzyanov, F.R. Gabitov, Z.I. Zaripov, M.I. Farakhov, A.V. Mukhutdinov. Supercritical fluid propane-butane extraction treatment of oil sludge. Supercritical Fluids: Theory and Practice. 2016. Vol.11. No.2. P.75-83. (Russian); F.M. Gumerov, M.I. Farakhov, V.F. Khairutdinov. Oil sludge utilization technology using liquid and supercritical fluid extraction with propane-butane extractant. Theoretical foundations of chemical technology. 2017. Vol.51. No.6. P.629-636. (Russian)

[13] L.V. Gurvich et al. The energies of breaking chemical bonds. Ionization potentials and electron affinity. Moscow: Science. 1974. 351p. (Russian)

[14] I.V. Berezin, E.T. Denisov, N.M. Emanuel. Oxidation of cyclohexane. 1962. Moscow: Publishing house of Moscow University. 302p. (Russian)

[15] G.K. Galina, S.I. Spivak. Induction period of hydrocarbon oxidation reactions in the liquid phase, described by differential equations. Bulletin of the Bashkir University. 2006. No.1. P.47-51. (Russian)

[16] E.T. Denisov. New empirical models of radical separation reactions. Advances in chemistry. 1997. Vol.66. No.10. P.953-971; E.T. Denisov. Radical addition reactions: factors that determine the activation energy. Advances in Chemistry. 2000. Vol.69. No.2. P.166-177. (Russian)

[17] E.T. Denisov, T.G. Denisova. Bimolecular reactions of radical generation. Advances in Chemistry. 2002. Vol.71. No.5. P.477-499. (Russian)

[18] Denisov E.T., Mitskevich N.I., Agabekov V.E. Liquid-Phase Oxidation of Oxygen-Containing Compounds. Consultants Bureau, New York. 1977. P.1-355.

[19] E.T. Denisov. Journal of Physical Chemistry. 1978. Vol.52. No.7. P.1585-1597; E.T. Denisov, G.I. Kovalev. Oxidation and stabilization of jet fuels. Moscow: Chemistry. 1983. 272p. (Russian)

[20] Denisov E.T., Mitskevich N.I., Agabekov V.E. Liquid-Phase Oxidation of Oxygen-Containing Compounds. Consultants Bureau, New York. 1977. P.1-355. 